BBA 65586

\title{
5-AMINOLAEVULINATE HYDRO-LYASE FROM YEAST ISOLATION AND PURIFICATION
}

OFELIA L. CLARA DE BARREIRO

Cátedra de Quimica Biológica I, Facultad de Ciencias Exactas y Naturales, Universidad de Buenos Aires, Periu 222, Buenos Aires (Avgentina)

(Received September Izth, 1966)

SUMMARY

An enzyme, aminolaevulinate dehydratase (5-aminolaevulinate hydro-lyase (adding 5-aminolaevulinate and cyclizing), EC 4.2.I.24), which catalyzes the following reaction:

2 5-aminolaevulinate $\stackrel{-\mathrm{H}_{2} \mathrm{O}}{\longrightarrow}$ porphobilinogen

has been isolated from yeast. Its purification and some of its properties have been studied. 5-Aminolaevulinate synthetase, another enzyme involved in porphyrin biosynthesis, has been detected in the mitochondrial particles.

\section{INTRODUCTION}

The biosynthesis of porphyrins in respiration-deficient mutants of Saccharomyces cerevisiae, grown under special conditions, was described by SUGIMURA et al. ${ }^{1}$. This fact and the presence of cytochrome in normal yeast would indicate that all the enzymes related to porphyrin biosynthesis should be present. Nevertheless, GiBson, NEUBERgER AND SCOTT ${ }^{2}$ could not find activity of aminolaevulinate dehydratase (5-aminolaevulinate hydro-lyase (adding 5-aminolaevulinate and cyclizing), EC 4.2.I.24) in this microorganism. This paper describes the isolation, purification and a kinetic study of this enzyme in yeast.

A method for the disruption of the yeast cell membrane, which allowed the detection of aminolaevulinate dehydratase in the supernatant fraction and of aminolaevulinate synthetase in the mitochondria, is also reported.

\section{MATERIALS AND METHODS}

I. The study was made on S. cerevisiae in steady state. Several methods for disrupting the membrane were tried: manual treatment of frozen cells in a mortar and a French pressure cell. The use of a Raytheon IoK sonic oscillator for 15 min with glass beads was less effective but allowed the assay of aminolaevulinate synthetase 
in the mitochondria. The most convenient and practical method was lyophilization of a thick suspension of cells in water, followed by grinding of the dry powder, suspended in acetone, with a Virtis homogenizer, at $40000 \mathrm{rev} . / \mathrm{min}$ for $20 \mathrm{~min}$. For this operation the glass container was placed in a solid $\mathrm{CO}_{2}$-alcohol bath. After filtration and washing with cold acetone and ether, a very stable powder was obtained which maintained its activity for several months.

2. 5-Aminolaevulinate was purchased from Sigma Chemical Company (St. Louis, Mo.).

3. $\mathrm{Ca}_{3}\left(\mathrm{PO}_{4}\right)_{2}$-gel was prepared according to $\mathrm{CoLOwICK}^{3}$.

4. DEAE-cellulose from Serva $(0.84 \mathrm{mg} / \mathrm{g})$ was used as described by PeTErson AND SOBER ${ }^{4}$.

5. Estimation of 5-aminolaevulinate and porphobilinogen was made by te methods of ShUSTER ${ }^{5}$ and URATa AND GRANICK ${ }^{6}$, respectively. Porphobilinogen was prepared in our laboratory according to the method of Cookson AND RIMINGTON?.

6. Protein estimations were made ( $\mathrm{mg}$ of protein per $\mathrm{ml}$ of enzyme solution) using the method of Lowry et al. ${ }^{8}$.

7. The estimation of aminolaevulinate dehydratase activity was made in a similar way to Gibson's experiments ${ }^{2}$. Thunberg tubes were used to measure the enzymic activity. In general, the system contained the enzyme fraction (dissolved in $20 \mathrm{mM}$ glycine buffer at the desired $\mathrm{pH}$ ), a buffer whose molarity ranged from $60 \mathrm{mM}$ to Ioo $\mathrm{mM}$, and the substrate dissolved in the same buffer or adjusted to the same $\mathrm{pH}$. The final volume was I $\mathrm{ml}$.

Deproteinization was effected using $0.4 \mathrm{ml}$ of $0.3 \mathrm{M}$ trichloroacetic acid.

The adsorption of porphobilinogen to the protein fraction used, ranged between I 2 and $20 \%$, according to the porphobilinogen concentration. In the presence of $9.5 \mathrm{mg}$ of protein per $\mathrm{ml}$, recoveries of 80 and $88 \%$ were obtained for concentrations of porphobilinogen of I $\mu \mathrm{M}$ and Io $\mu \mathrm{M}$, respectively. The same concentrations were used for the $K_{m}$ determinations; the corresponding corrections for each point of $\mathrm{I} / \mathrm{v}$ were made.

Since the activities of the enzyme preparations were low, deproteinization with colloidal $\mathrm{Fe}_{2} \mathrm{O}_{3}$ and $\mathrm{CuSO}_{4}$ did not give satisfactory results.

8. The extraction and estimation of aminolaevulinate synthetase was effected as follows: $\mathrm{I} 5 \mathrm{~g}$ of yeast was suspended in a mixture of $0.25 \mathrm{M}$ sucrose, $20 \mathrm{mM}$ Tris buffer ( $\mathrm{pH} \mathrm{7.4)}$ and $5 \mathrm{mM}$ EDTA, and then submitted to sonication. Mitochondria were obtained by differential centrifugation at $70000 \times g$, following a preliminary separation of "débris cellulaires" at $7000 \times \mathrm{g}$. The pellet was treated with $20 \mathrm{mM}$ thioglycollate, $0.25 \mathrm{M}$ sucrose, Io $\mathrm{mM}$ Tris buffer $(\mathrm{pH} 7.4$ ) and $5 \mathrm{mM}$ EDTA for $\mathrm{I} h$. The aerobic system of incubation consisted of $50 \mathrm{mM}\left[2^{-14} \mathrm{C}\right]$ glycine $(2.7 \mu \mathrm{C}), 0.5 \mathrm{mM}$ ATP, $0.25 \mathrm{mM}$ succinyl-CoA (prepared according to SIMON AND SHEMIN ${ }^{9}$ ), $30 \mathrm{mM}$ $\mathrm{KCl}, 6 \mathrm{mM} \mathrm{MgCl}_{2}, 0.2 \mathrm{ml}$ of mitochondria suspension, representing $5 \mathrm{~g}$ of fresh yeast, $50 \mathrm{mM}$ Tris buffer, $\mathrm{pH} \mathrm{7.4}$, and $\mathrm{I} 25 \mathrm{mM}$ pyridoxal phosphate, in a final vol. of $2.0 \mathrm{ml}$. After incubation at $37.2^{\circ}$ for $\mathrm{I} h$, the system was deproteinized with $0.2 \mathrm{ml}$ of $0.3 \mathrm{M}$ trichloroacetic acid. The pyrrols formed according to MAUzERALL AND Granick ${ }^{\mathbf{1 0}}$, were extracted with ether at $\mathrm{pH}$ I.o and submitted to chromatography on Whatman No. I paper. The chromatograms were scanned in a Packard radiochromatogram scanner, Model 7200. 
RESULTS

Purification of aminolaevulinate dehydratase

A summary of the data on purification is presented in Table I. All operations were carried out between $0-4^{\circ}$.

\section{TABLE I}

PURIFICATION OF AMINOLAEVULINATE DEHYDRATASE

Experimental details are given in the text.

Fraction

Protein Specific activity

(mg/ml) (mumoles porphobilinogen

per $m g$ protein per $h$ )

Step 1 : supernatant fraction obtained from centrifuging

at $78000 \times g$

Step 2 : redissolved precipitate obtained from treatment with $\left(\mathrm{NH}_{4}\right)_{2} \mathrm{SO}_{4}(30-50 \%$ satn. $)$

Step 3: supernatant fraction after treatment with

$\mathrm{Ca}_{3}\left(\mathrm{PO}_{4}\right)_{2}$ gel

Step 4 : eluted from DEAE-cellulose column

$\begin{array}{lr}37.0 & 5.1 \\ 28.5 & 22.7 \\ 7.1 & 49 \\ 0.02 & 4700\end{array}$

Extraction of the enzyme. The dry acetone powder was treated with $20 \mathrm{mM}$ buffer (20 $\mathrm{g} /$ Ioo $\mathrm{ml}$ of buffer) using a magnetic stirrer, in a two-step operation. The buffer was selected according to the study to be made with the solubilized proteins contain-
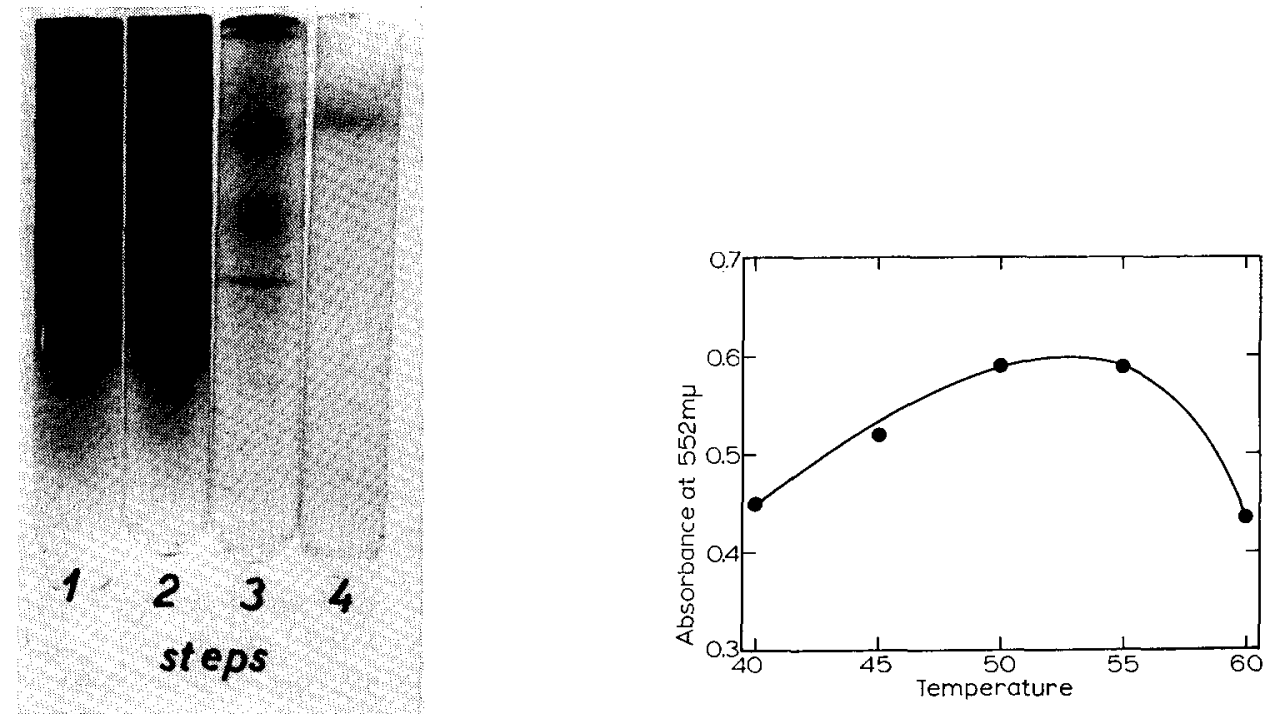

Fig. I. Stages of purification of aminolaevulinate dehydratase as monitored by polyacrylamidegel electrophoresis using barbital buffer ( $\mathrm{pH} 8.6 ; I=\mathrm{O} . \mathrm{I}$ ).

Fig. 2. Optimal temperature. The incubation mixture contained o. I M glycine-NaOH buffer, $5 \mathrm{mM}$ 5-aminolaevulinate and $0.2 \mathrm{ml}$ of the enzyme fraction from Step 2. The final volume was I $\mathrm{ml}$. Incubations were performed for $30 \mathrm{~min}$. 
ing the enzyme. The buffered solution extracted from yeast was spun at 18 ooo $\times g$ for $\mathrm{I} 5 \mathrm{~min}$ and then at 78 ooo $\times g$ for $\mathrm{I} h$ (Step I). A non-viscous solution was thus obtained with which reproducible fractionation steps using $\left(\mathrm{NH}_{4}\right)_{2} \mathrm{SO}_{4}$ may be carried out. After testing different salt concentrations, most of the enzyme activity was found in the fraction obtained at $30-50 \%$ satn. (Step 2). This fraction was dialyzed against $20 \mathrm{mM}$ phosphate buffer ( $\mathrm{pH} 7.6$ ) to allow further purification. For inhibition assays, $20 \mathrm{mM}$ sodium phosphate buffer ( $\mathrm{pH}$ 6.8) was used, but the enzyme flocculated within a few hours in this buffer and became inactive.

Purification on $\mathrm{Ca}_{3}\left(\mathrm{PO}_{4}\right)_{2}$ gel. The dialyzed fraction obtained from Step 2 was treated with 4 portions of $\mathrm{I} \mathrm{ml}$ of $\mathrm{Ca}_{3}\left(\mathrm{PO}_{4}\right)_{2}$ gel $(32 \mathrm{mg} / \mathrm{ml})$. The latter was eluted with o.I $\mathrm{M}$ glycine buffer ( $\mathrm{pH}$ 9.6) containing $5 \%\left(\mathrm{NH}_{4}\right)_{2} \mathrm{SO}_{4}$. Most of the enzyme remained in the supernatant fraction (Step 3).

Purification on DEAE-cellulose. The supernatant fraction obtained from Step 3 was dialyzed against Io $\mathrm{mM}$ glycine buffer $(\mathrm{pH} 7.7)$. It was then passed through a DEAE-cellulose column, equilibrated with Io $\mathrm{mM}$ glycine buffer ( $\mathrm{pH}$ 7.7). Protein was eluted from the column by increasing the molarity of the glycine buffer from to to $200 \mathrm{mM}$ in a stepwise fashion (Step 4). Four peaks were obtained of increasing enzymic activity at glycine molarities of approx. 20, 50, 100 and $200 \mathrm{mM}$, the most active being that eluted with the greatest ionic strength buffer. The results obtained and the increases in specific activity at each step are shown in Table I.

Purification of the enzyme was followed by electrophoresis on polyacrylamide, using the technique of Raymond and WeInTRAuB ${ }^{11}$ (Fig. I).

\section{Optimal Temperature}

As shown in Fig. 2, the optimal temperature range was $50-55^{\circ}$.
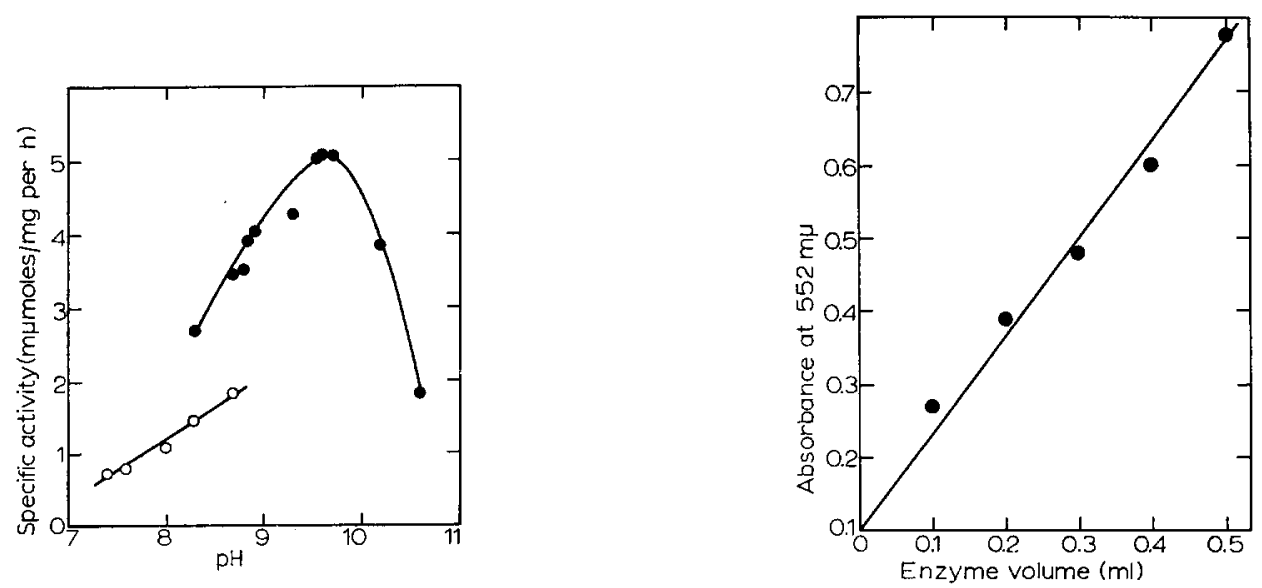

Fig. 3. Optimal pH. The system contained: $5 \mathrm{mM} \mathrm{5-aminolaevulinate,} \mathrm{I}$ oo $\mathrm{mM}$ Tris buffer or $70 \mathrm{mM}$ glycine buffer and $0.3 \mathrm{ml}$ or $0.2 \mathrm{ml}$ of the enzyme fraction from Step 2 for each buffer, respectively. Incubations were performed at $38^{\circ}$ for $60 \mathrm{~min}$ when Tris buffer (O) was used and at $55^{\circ}$ during $30 \mathrm{~min}$ when glycine buffer (O) was present.

Fig. 4. Relation between activity and enzyme concentration. The system contained: $60 \mathrm{mM}$ glycine- $\mathrm{NaOH}$ buffer ( $\mathrm{pH}$ 9.6), $5 \mathrm{mM}$-aminolaevulinate, and the supernatant fraction treated with $30 \%\left(\mathrm{NH}_{4}\right)_{2} \mathrm{SO}_{4}$ and containing $25 \mathrm{mg}$ protein per $\mathrm{ml}$. The final volume was $\mathrm{I} \mathrm{ml}$ and the temperature of incubation $55^{\circ}$. 


\section{Optimal $p H$}

Buffer systems ranging from $\mathrm{pH} 5.95$ to ro.6 were assayed. In each case the $30-50 \%$ fraction from Step 2 was dissolved in the appropriate buffer and dialyzed against it. The $\mathrm{pH}$ of the incubation mixture was measured before and after incubation. Determinations made in a carbonate-bicarbonate system failed to give concordant values, perhaps due to the dissociation of the bicarbonate anion when it was incubated in vacuo; it was found that the $\mathrm{pH}$ did not maintain its value. The optimal $\mathrm{pH}$ was obtained in glycine- $\mathrm{NaOH}$ buffer between $\mathrm{pH} 9.5$ and 9.7 (Fig. 3.).

\section{Relation between activity and enzyme concentration}

A linear relation between these factors was maintained under the conditions of the experiment (Fig. 4).

\section{Determination of $K_{m}$}

Since the optimal $\mathrm{pH}$ was about $9 \cdot 5-9.7$, the $K_{m}$ measurements were made in an alkaline medium. It was observed that the substrate solution turned violet-red in this medium. According to NEUBERGER AND SCOTT ${ }^{12}, 5$-aminolaevulinate forms a 2,5disubstituted pyrazinyl derivative at these $\mathrm{pH}$ values. It was necessary therefore to

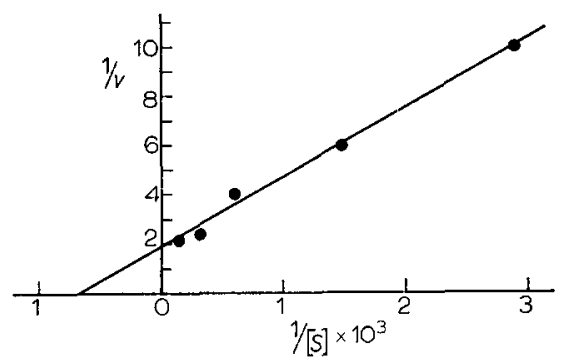

Fig. 5. Determination of $K_{m}$. The system contained: $80 \mathrm{mM}$ glycine-NaOH buffer (pH 9.6), 5-aminolaevulinate ranging from $0.345 \mu \mathrm{M}$ to $6.45 \mu \mathrm{M}$ and o. I ml of the enzyme fraction (Step 2 ) representing $9.5 \mathrm{mg}$ of protein. Incubations were performed at $55^{\circ}$ for $30 \mathrm{~min}$. Results are plotted as $\mathrm{I} /$ absorbance and $\mathrm{I} /[S]$ : absorbance represents initial reaction rate; $[S]$ is expressed as molar concentrations of 5 -aminolaevulinate.

evaluate the residual 5-aminolaevulinate at each point of the $K_{m}$ determination. At $\mathrm{pH} 9.5$, a $30 \%$ conversion was observed with all 5 -aminolaevulinate concentrations used. The $K_{m}$ value obtained, under optimal conditions, was I.5 mM (Fig. 5).

\section{Effect of inhibitors}

As the aminolaevulinate dehydratases studied in different organisms and tissues are sulfhydryl enzymes, tests with classic inhibitors were made. To avoid decomposition of the reagent $\mathrm{SH}$ groups in the alkaline medium, sodium phosphate buffer ( $\mathrm{pH}$ 6.8) was used, in spite of the low enzyme activity at that $\mathrm{pH}$. The results obtained indicate that it is also a sulfhydryl enzyme (Table II).

Glutathione and cysteine, under special conditions, were found to be inhibitors of the enzyme, although random values were obtained. It may be assumed that the substrate inhibition by the $\mathrm{SH}$ groups takes place on the highly reactive ketonic group of 5-aminolaevulinate. 
TABLE II

ASSAYS OF INHIBITION

The percentage of inhibition is calculated with respect to the activity of the following mixture: $60 \mathrm{mM}$ sodium phosphate buffer $(\mathrm{pH} \mathrm{6.8)}, 5 \mathrm{mM} 5$-aminolaevulinate and o.I $\mathrm{ml}$ of the enzyme from Step 2 . The final volume is $\mathrm{I} \mathrm{ml}$. Porphobilinogen was estimated as described under MATERIALS AND METHODS.

\begin{tabular}{ll}
$\begin{array}{l}\text { Inhibitor } \\
(I \mathrm{mM} M)\end{array}$ & $\begin{array}{l}\text { Inhibition } \\
(\%)\end{array}$ \\
\hline N-Ethylmaleimide & 30 \\
Iodoacetamide & 55 \\
$5,5^{\prime}$-Dithio-bis(2-nitrobenzoic acid) & 85 \\
p-Chloromercuribenzoate & 85 \\
$\mathrm{Hg}^{2+}$ & 90 \\
$\mathrm{Cu}^{2+}$ & 90 \\
\hline
\end{tabular}

To obtain inhibition curves, according to $\mathrm{WEBB}^{13}$, it is necessary to know $K_{*}$ (the substrate constant). Since $K_{s}$ could not be determined up to now, estimation of the SH group of cysteine in the presence of 5 -aminolaevulinate was measured according to Grunert and Phillips ${ }^{14}$. The results are shown in Table III. $\mathrm{Mg}^{2+}$, assayed in Tris buffer, had no effect on porphobilinogen biosynthesis. As is the case for other dehydratases, Tris buffer acted by partially inhibiting the enzyme, with respect to sodium phosphate buffer. The addition of I mM EDTA to the medium containing sodium phosphate buffer $(\mathrm{pH} 6.8)$ leads to approx. $35 \%$ inhibition of the enzymic activity. $\alpha, \alpha^{\prime} 5$-dipyridyl at I mM did not inhibit the enzyme.

\section{TABLE III}

INTERACTION BETWEEN 5-AMINOLAEVULINATE AND CYSTEINE

Cysteine (I mM) was incubated with o.I M phosphate buffer ( $\mathrm{pH} 7.6$ ) and the indicated amounts

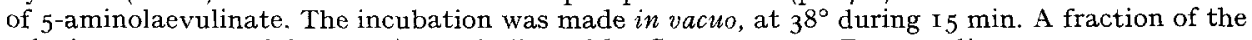
solution was assayed for cysteine as indicated by GrunERT AND PHILlips ${ }^{14}$.

\begin{tabular}{|c|c|}
\hline $\begin{array}{l}\text { 5-Amino- } \\
\text { laevulinate } \\
\text { ( } \mu \text { moles) }\end{array}$ & $\begin{array}{l}\text { Absorbance at } \\
520 \mathrm{mu}\end{array}$ \\
\hline 0 & 0.290 \\
\hline 0.5 & $0.24 \mathrm{I}$ \\
\hline I.O & 0.229 \\
\hline 2.5 & 0.200 \\
\hline
\end{tabular}

\section{DISCUSSION}

Aminolaevulinate dehydratase has been isolated from several biological sources: mammalian tissues ${ }^{2}$, Rhodopseudomonas spheroides ${ }^{15}$, propionic acid bacteria ${ }^{16}$, etc. In all cases, the enzyme acts in the second step in the pathway of tetrapyrole biosynthesis, thus leading to the formation of heme, chlorophyll, etc., depending on the biological source.

The normal yeast, studied in the present paper, shows a low activity of aminolaevulinate dehydratase, at least under biological $\mathrm{pH}$ and temperature. For instance 
the extract obtained from the acetone powder (the latter representing $33 \%$ in dry weight) only yielded $5 \mathrm{~m} \mu$ moles/mg per $\mathrm{h}$, a much lower activity than those reported for aminolaevulinate dehydratase from other sources. The same was true for aminolaevulinate synthetase for which, in a radioactivity uptake experiment, an incorporation of 540 counts $/ \mathrm{min}$, representing $0.08 \%$ of added counts, was obtained. The final products can vary quantitatively, depending on the culture medium in which the yeast is grown.

According to WALLACE AND LINNANE ${ }^{17}$, using an anaerobic medium with $5 \%$ glucose, an enhancement of porphyrin biosynthesis is obtained, relative to that of cytochromes. Therefore, a high activity of the related enzymes can be expected to be found in that medium.

This enzyme exhibited a $\mathrm{pH}$ optimum of $9 \cdot 5-9 \cdot 7$, very different from that reported by GibSon, NeUBERGER AND ScotT ${ }^{2}$ for the enzyme from ox liver ( $\mathrm{pH} 6.8$ ), by WALERYCH ${ }^{16}$ for that from propionic acid bacteria $(\mathrm{pH} 7$ ), by M. TomIo (personal communication) for Harderian rat gland ( $\mathrm{pH}$ 6.8) and by BURNHAM AND LASCELLES ${ }^{15}$ for $R$. spheroides ( $\mathrm{pH} 7.8-8.0$ ). The optimal temperature $\left(50-55^{\circ}\right)$ was found to be similar to that for the enzymes from propionic acid bacteria $\left(60^{\circ}\right)$ and Harderian gland $\left(55^{\circ}\right)$.

From the inhibition reactions performed, it was deduced that it is also a sulfhydryl enzyme. The studies of NANDI AND SHEMIN ${ }^{18}$ with aminolaevulinate dehydratase from $R$. spheroides demonstrated that there is the formation of a Schiff base between the substrate 5 -aminolaevulinate and a basic amino acid of the enzyme. This allows us to explain the inhibition by SH groups (Table III) as being due to the interaction of cysteine SH groups with the keto group of the substrate, thus diminishing the substrate concentration.

In general, on the basis of several activity determinations in the presence of cysteine, it is possible to conclude that at high substrate concentrations, the activation of the enzyme by $\mathrm{SH}$ groups prevails with respect to the interaction between SH groups and 5-aminolaevulinate; this problem needs further investigation and kinetic studies are in progress.

\section{ACKNOWLEDGEMENTS}

The author wishes to thank Dr. J. CASTAGnino (Cátedra de Análisis Biológicos, Facultad de Ciencias Exactas y Naturales) for his help and assistance in carrying out the polyacrylamide-gel electrophoresis and to Dr. MARY Tomio (Cátedra de Química Biológica, Facultad de Ciencias Exactas y Naturales) for her collaboration in the assay of aminolaevulinate synthetase.

This work was supported in part by a research grant from the Consejo Nacional de Investigaciones Científicas y Técnicas (Argentina).

\section{REFERENCES}

I T. Sugimura, K. Okabe, M. Nagao and N. Gunge, Biochim. Biophys. Acta, i I5 (I966) 267.

2 K. D. Gibson, A. Neuberger and J. J. Scott, Biochem. J., 6i (1955) 6 I 8.

3 S. P. Colowick, in S. P. Colowick and N. O. Kaplan, Methods in Enzymology, Vol. I, Acałemic Press, New York, 1955, p. 90.

4 E. A. Peterson and H. A. Sober, J. Am. Chem. Soc., 78 (1956) 75 I.

5 L. Shuster, Biochem. J., 64 (1956) Ior. 
6 G. URata and S. Granick, J. Biol. Chem., 238 (1963) 8I I.

7 G. H. Cookson and C. Rimington, Biochem. J., 57 (1954) 476.

8 O. H. Lowry, N. J. Rosebrough, A. L. Farr and R. J. Randall, J. Biol. Chem., I93 (I95I) 265.

9 E.J. Simon and D. Shemin, J. Am. Chem. Soc., 75 (1953) 2520.

io D. Mauzerall and S. Granick, J. Biol. Chem., 2 I9 (I956) 435.

i I S. Raymond and L. Weintraub, Science, izo (I959) 7 I I.

i 2 A. Neuberger and J. J. Scott, J. Chem. Soc., (I954) I820.

I 3 J. L. WebB, in J. I. WEBB, Enzyme and Metabolic Inhibitors, Vol. I, Academic Press, New York, I963, p. 85 .

I 4 R. Grunert and P. H. Phillips, Arch. Biochem., 30 (I95I) 217.

I 5 B. F. Burnham and J. Lascelles, Biochem. J., 87 (1963) 462.

I6 W. Walerych, Acta Biochim. Polon., ro (I963) 243.

I 7 P. G. Wallace and A. W. Linnane, Naluve, 20 I (I964) IIgr.

I8 D. L. Nandr and D. Shemin, Federation Proc., 24 (1965) 53 I.

Biochim. Biophys. Acta, I39 (I967) 479-486 